\title{
BIRD STUDY IN NEW ZEALAND
}

\author{
By Perrine Moncrieff
}

New Zealand might be described as a land of surprises done up in very small parcels. It has many minerals, but these, owing to past upheavals, are seldom in payable quantities. Distributed over the country in pockets, they affect the soil which, in turn, has a bearing upon plant and bird life. Due to this and climatic conditions a botanist will find different plants as he passes from Norfolk Island towards the Antarctic. Some of them occur in one small area and nowhere else.

Bird life follows a somewhat similar pattern. Few native species are distributed throughout the Dominion. It is possible, for example, to pass from poor beech forest, on granite formation, where few species except native robins can exist, into a patch of limestone where, owing to the difference in soil, fine berrybearing trees support not only a large population but different species of birds.

The "parcel " simile can be carried a step further when one takes into consideration that certain islands each have their own peculiar species, for example, the Antipodes Island Parrakeet, the Snares Island Robin, and the extinct Stephen Island Wren.

Even a valley may contain special birds, such as a race of woodhens (Gallirallus) which, before they were killed out, varied from the usual South Island colouring by having a white neck and breast. It is therefore quite feasible that the list of New Zealand plants and birds is not complete. There is also the hope that some bird believed to be extinct may be found again, even if it is not so spectacular as a moa, and in the light of recent events one can predict that more stragglers from Australia will establish themselves within the Dominion.

The problems which confront those who desire to study birds in New Zealand are discussed below, from the public and from the scientific standpoint.

Certain species are mainly nocturnal, such as kiwis, which the average New Zealander is more likely to see upon a stamp than in their native habitat. Granted that at a government farm in North Island a North Island Kiwi may be seen hatching out his wife's egg, and the brown plumage and unusual nostril position observed; but this is hardly the same as watching in the wilds.

The writer concurs with Dr. K. Crompton's remarks (The Countryman, vol. xlii) where he says that the male of this living 


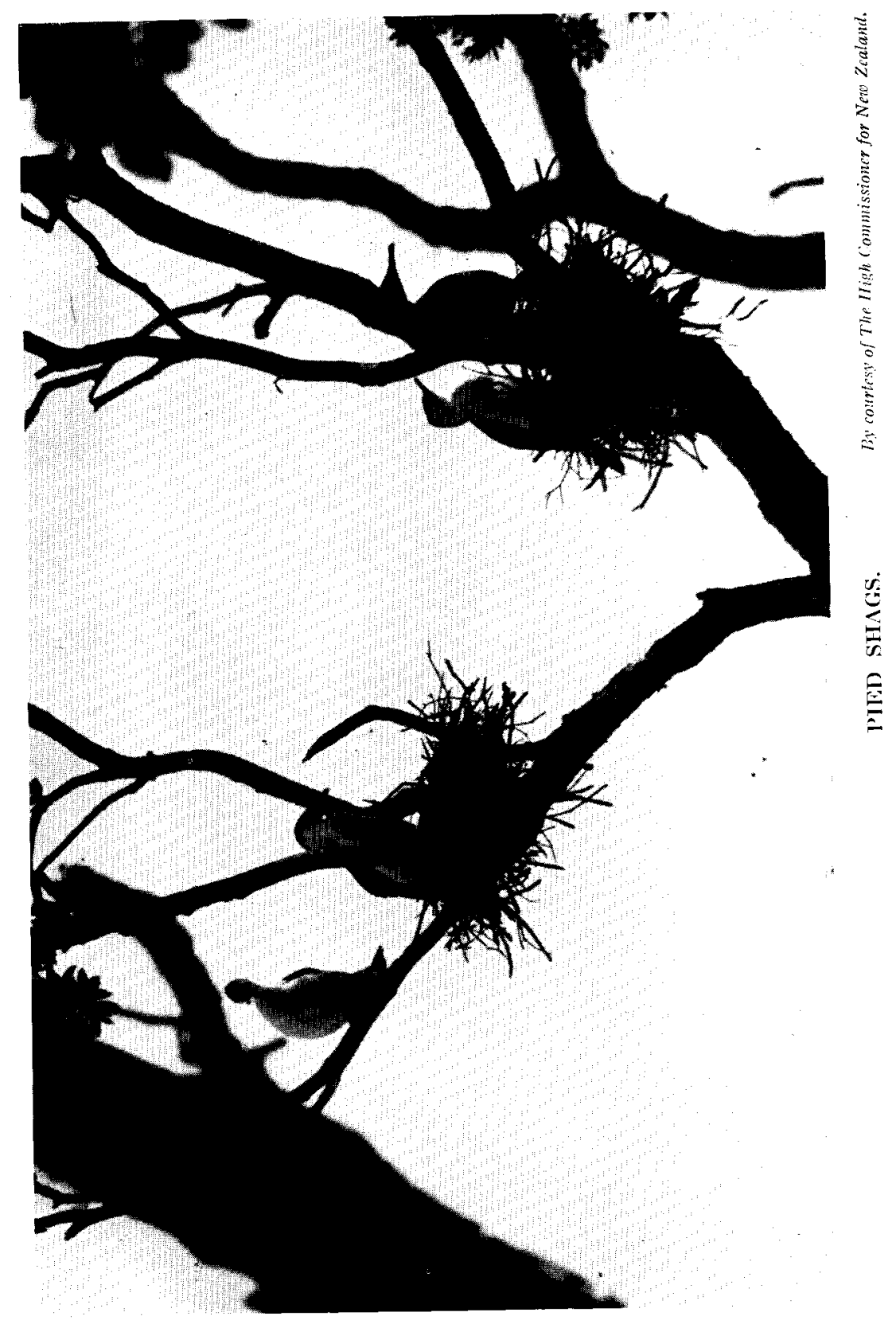


fossil may take on the duty of rearing the chick in order to enable the $f \in$ male to recover from the strain of laying so large an egg. This is in accordance with Dr. Julian Huxley's theory.

Whilst not particularly rare, two South Island kiwis, the Little Grey Kiwi of soft grey plumage, and its larger relative, the South Island Kiwi, are most likely to be met with when their corpses come down a sluicing race. The writer has found the former's tracks in mud around the roots of a large tree high on the mountain side. There were adult and juvenile footprints followed, alas, by the pads of a large cat. On another occasion a pair were observed sniffing round a haunch of venison hanging from a tent-pole. They obviously liked the smell of fresh meat and called "Kee-vee-vee" to one another in considerable excitement.

When handled the kiwi's lizard-like trait of shedding as many feathers as would stuff a small cushion, and yet appearing as neat as before, has to be seen to be believed.

A large portion of New Zealand birds are seabirds, comprising small and large members of the petrel family which come ashore, generally on islands, to breed. The neighbourhood of Auckland affords excellent opportunities to study their habits, when they return nightly to their burrows and feed their chicks.

On Hen Island (a sanctuary without a caretaker) it is possible to study petrels by night and the rare Saddleback, a species of starling, by day. In this locality the Saddleback, once common on the mainland, appears to pass from nestling into adult plumage direct. In the south it assumes a transition stage, which led former naturalists to take it for a distinct species.

On islands around Stewart Island different petrels are to be found, such as the Sooty Shearwater or "Muttonbird"1, so called because the young when the size of a small chicken are good eating. The right to collect them is vested in certain Maori families who make a special expedition to "The Muttonbird Islands" for that purpose. These shearwaters, like a number of others, range far afield. The writer's uncle, J. G. Millais, stated that he had come across solitary muttonbirds in Norway, where, however, they did not breed. When it is time for them to nest the birds return with amazing punctuality. They fly in from the ocean in long unbroken formation which, like an immense army, will file past a ship for days on end. On reaching their particular island home, each

1 Editorial Note.-The Sooty Shearwater (Puffinus griseus), the "muttonbird" of New Zealand, must not be confused with the Short-tailed Shearwater (Puffinus tenuirostris), the "muttonbird" of the Bass Strait. 
band detaches itself from the main flight with marvellous precision, and individual birds descend earthward to start cleaning out the burrows they occupied the year before-that is to say if the owners have survived that long.

The flight of petrels returning to land to breed and their nightly arrival from the sea to feed their young is a sight that no one should miss.

Larger members of the same order of Tubinares, such as albatross, are seldom seen close inshore and most breed on remote islands far south. But of recent years Otago Heads (South Island) has been sought out by a pair of Royal Albatross to rear their chicks. At times exhausted birds are picked up upon the beach near Nelson. Thus, a Royal sat for some weeks amongst cabbages in a garden, content to be fed where it had been placed, and on one occasion very nearly consumed a litter of puppies which had wandered too close to its beak, open wide to devour them.

The sight of small Maori children sitting cross-legged round another albatross was reminiscent of Alice and the Dodo; whilst a huge Giant Petrel thrust into the writer's arms in the dark proved as embarrassing as Alice playing croquet with a flamingo. This exhausted bird was revived by cod-liver oil greedily sucked from a bowl of water, which proved so popular that a yard-broom was needed to fend off the excited prods from "Nelly" when she felt hungry.

Some months later there appeared in an Australian newspaper the report of a savage Giant Petrel which had attacked two women walking on the beach, making one wonder whether "Nelly" had been at her tricks again to get cod-liver oil.

Remote islands of the sub-Antarctic are the place to observe albatross and penguin. But fortunately visitors can see the Yellow-eyed Penguin on Stewart Island where they nest in damp forest between wild ocean beaches and calm inland waters. Here one may chance upon them leaping from the water after the manner of a porpoise.

Making for Snares Island to breed, Rockhopper Penguins sometimes come ashore on the east coast of South Island. Once spectators were appalled by the sight of several hundred of these birds fouled by oil awaiting death beside already dead companions. Fortunately such incidents are few since shipmasters have been warned against releasing oil too close inshore.

In Tasman Bay (Nelson Province) the Little Penguins still come ashore at dusk, landing from waves to scurry inland like rats. Occasionally they will be found 600 feet up; at other 
times they may be fished out of a well. No one has yet explained why some wander inland up steep hills when there are suitable sites close to the beach. In early days they would come and sit round an open fire upon the beach, appearing to enjoy the warmth. But in these days of stoats they are less confiding.

The migratory movements of shags ${ }^{1}$ have yet to be studied. In Nelson Province (Tasman Bay) different species are in residence during winter and summer. Deprived of their former roosting site Pied Shags have taken to sleeping on the top of Norfolk Island pines along the main road.

Shags are best studied in Stewart Island where the inhabitants are proud of their numerous species, especially the handsome Bronze Shags which roost on small islands in inland waters. Black and white shags festoon the trees at the water's edge with rook-like nests, whilst the nests of Blue Shags have hung for years secured to a steep rock face. Blue Shags were formerly eaten by sailors and nearly exterminated, but fortunately are now on the increase. Not so the Carunculated or Rough-faced Shags, which dwell upon islands in Marlborough Sounds and nowhere else. These protected birds resemble the Bronze Shags and might increase if they were not shot under the impression that all shags are enemies of fish. The Black Shag has been so severely persecuted that it has disappeared from many localities, but still survives in out-of-the-way places. Last year some 400 of these birds migrated over Nelson city at chimney level, much to the amazement of everybody. Their flight is most interesting. They change at full speed from " $V$ " into " $W$ " formation. The "W's" then flatten out so that when the leader drops seaward he is followed by a huge flock of shags all in single file. In fine weather they have the habit of playing like rooks; they circle upwards till almost out of sight, then sudenly drop earthward after the manner of dive-bombers.

The famous White Egrets of New Zealand, pride of the Maoris, who believed death was the punishment of those who slew this princely bird, have their sole heronry up a lonely semi-tropical river beyond a vast South Island lagoon, in proximity to a shaggery, from which they obtain scraps. History has recently been made by the addition of two Australian spoonbills nesting in the tree-ferns amongst the Egrets. The small bluish-coloured Reef Heron is common along the coast of New Zealand and quite recently the White-faced Heron of Australia has established itself in Nelson Province.

1 Editorial Note.-Except in the British Isles the terms "cormorant" and "shag" may be regarded as interchangeable. 
A small number landed where they were not molested and have since spread along the coast and even nest in trees above the houses of a small settlement. This indicates clearly that New Zealand could have many Australian species if vandals would refrain from shooting them when they arrived in this country.

A true picture of the birds of New Zealand cannot be obtained without considerable travel. They must be sought in all kinds of country and often under very rough conditions. In addition, certain species are found only in the North Island, others only in the South Island. The Stitchbird, for example, must be sought on Little Barrier Island sanctuary where glimpses can be caught of this unique species as it flits through the dense vegetation.

The notorious Kea parrot dwells in the South Island, where it delights tourists with its antics. Stories about Keas tend to resemble fishermen's yarns. But the complaint that no bible could be kept in a hotel bedroom because Keas used the pages for nesting material, is not entirely myth. These birds, alleged to be sheep-killers, though many never see a sheep in their lives, are too frequently depicted pulling at a carcase. Thus, the world in general fails to appreciate the fact that they are invaluable distributors of montane plants, which clothe the mountain tops and prevent erosion.

Still more unfortunate is it that the valuable Kaka parrot, of which there is a North and a South Island species, is slain because of its superficial resemblance to a Kea, whose musical call "Kee-ah" is quite unlike the raucous shriek of our best ally against beetles. Nowadays it is hard to ensure seeing a Kaka. In days gone by they passed along the coast of Tasman Bay in serried ranks for hours on end, returning from feasting on rata honey from the vast North Island forests, which also are no more.

In addition to the smallest bird in New Zealand, the wee Rifleman, which squeezes into a knot in a hollow tree to make a nest as large as a coconut, two small passerine birds exist, but only in the South Island, namely the Rock-Wren and the New Zealand Brown Creeper. Both have escaped publicity. The former dwells on mountains. The latter delights all who encounter a small flock roaming through the forest. Apart from being peculiar to the South Island, the Brown Creeper is the only New Zealand bird with a song containing the letter " $\mathrm{Z}$ ". The writer can endorse the statement of Johannes Anderson that more than one bird contributes in producing the joyous theme. 
It is necessary to travel widely in search of birds because certain species differ in size and colouring according to the island they are in. Whilst the British Robin is the same in whatever district it is sought, this bird's relative in New Zealand is smaller in the North than in the South Island and its plumage is slightly different. Tits (Petroica) are known as the Yellow or White-breasted Tit, according to which island they dwell in. The Blue-wattled Crow may yet be heard in the mountain ranges near Auckland, but it would be hard to say where to seek the Orange-wattled Crow of the South Island. Even in the alleged last stronghold of New Zealand birds, Stewart Island, it has not been seen for some years; its movements being akin to those of fantails, which flutter along the ground after insects, it doubtless fell a prey to cats.

The native thrush of the North Island credited with a song of five distinct bars has recently been rediscovered and it is hoped its wonderful notes will be recorded. The South Island Thrush though still in existence is so rare as to be deemed extinct. The genus Mohoua has two species, the Whitehead of the North and the Yellowhead of the South Island, both charming insect-eating birds. The Whitehead is the tamer, for the Yellowhead once it has had a good look at an observer is likely to move on without further interest. Its rippling spring song, like a shilling spinning, is poured out as the bird flits through the forest always following the direction of the sun. The writer has observed one feeding upon a caterpillar, holding it in its claw like a parrot.

The Black Fantail is rarely found in the North Island, where the Pied is common. One must cross Cook's Straits to see it. Individuals vary, some have a total dingy black plumage, others have about the ears a touch of white, which may be minute or as large as a threepenny bit.

It will be noticed that the yellow breast markings of the South Island Robin, the Yellow-breasted Tit, Yellowhead, and Orange-wattled Crow are all confined to the South Island. This would seem to indicate some factor in the soil which encourages the yellow pigments.

Certain, but not a great many species, may be seen in New Zealand without making any special effort. Among them is the small Grey Warbler, foster parent of the Shining Cuckoo. This warbler varies sufficiently by districts to be divided into subspecies; its song also differs according to locality, the most pleasing variation of the warbler theme being produced by montane sub-species. 
Visitors to New Zealand frequently complain that they see far too many British birds which have replaced native species. This, alas, is correct. Where an Australian is able to show some sixty or more species in a day, the average resident of New Zealand is more likely to see under forty during a life time.

Gulls and terns closely resemble those of the Old World and are common round the coast.

Game-birds are not endemic for, like the Australian Swamp Quail and Californian Quail, they were introduced to replace the native quail which is thought to be extinct. A new arrival, the Chukor partridge, appears likely to establish itself, for a party of forty was recently met with on Mount Robert, Nelson District.

The New Zealand Harrier is very common. It quarters the ground like a lovely brown butterfly and is responsible for the destruction of many rats, stoats, and rabbits. Less apparent but still plentiful is the New Zealand Falcon. This is a polymorphic species where the colouring is always similar, but there occurs a variation in size which is quite considerable. A small female averages 42 centimetres and a large one 48 centimetres. Early colonists called the large bird the Quail Hawk and the small type the Sparrow Hawk. These names have been so widely used that it will be hard to get the public to use the correct nomenclature. The smaller type is likely to survive ; it is less easily shot as it inhabits native forest or rocky gullies. It descends like a thunderbolt to attack those who ride within reach of its nest and is the enemy of both native and introduced pigeons.

Duck and teal may be seen on most lakes in New Zealand, including the Paradise Duck of the South Island, which has the interesting habit of nesting in a tree, whence it carries its young down to earth. Male and female have different colouring and call-notes. This duck is most unpopular with deer stalkers, warning all game of the presence of strangers by its wild cries of "Go back" and "Where, where". The interesting Blue or Mountain Duck, whose sibilant "Whee-oo" is designed to carry above the roar of waterfalls is, alas, scarce.

No difficulty will be cxperienced in observing the small New Zealand Owl with its weird cry of "Morepork". It may repeat the last syllable ad nauseam until, as with the British cuckoo, the hearer gets tired of counting. It is difficult to imagine these owls bathing but the writer has watched a pair emerge from a forest creek and preen their feathers after the manner of a damp sparrow. In Nelson certain Moreporks visit the sea coast during the winter and return to the forest to nest. Whilst on 
the whole they are insect-eaters, any shortage of this diet will lead to a change of habits, and the Morepork becomes a menace to small birds.

Among the victims of the Morepork is frequently the small White-eye which at times arrives from Australia in flocks. But these soon decline in numbers. Their nests are destroyed by fire and they themselves perish in orchards where the amount of aphis they devour is overlooked because of their habit of pecking fruit. Being honey-eaters, they investigate anything sweet; thus, some forty birds were poisoned by sipping antkiller from a saucer.

The very bird Captain Cook predicted would become extinct, namely the Bellbird, another honey-eater, appears to be on the increase. Its lovely notes are still heard but the famous Bellbird chorus is seldom heard now because it requires a number of birds for its performance.

The Tui, the third honey-eater of New Zealand, is an admirable mimic. Round cities it tends to learn ugly sounds, but near waterfalls sings to perfection. After hearing a violin played for ten days, birds within hearing were able to repeat a portion of the major scale, and a certain Tui whistled a considerable part of " The Campbells are Coming" from listening to the bagpipes. Maoris kept Tuis as pets despite their tendency to fits. One nearly precipitated a crisis in early days by calling from a dark corner above the Paramount Chief's head "The man's a liar" or words to that effect when certain European dignitaries had arrived to discuss terms of peace. A most pugnacious but intelligent bird, the tui will sip honey from bottles tied to trees for its use, raise its voice in angelic thanks, and then spoil the whole effect by breaking off to chase some small bird. It defends its young with great courage and will even tilt up its nest rather than permit its eggs to be taken. Whilst mainly a honeyeater, it feeds its young on insects and, towards evening, on spiders which appear to have great food value.

One may conclude the list of very common birds by mentioning the kingfisher, which lacks the beauty of its British relation. It appears to include almost anything in its diet, from small birds, lizards, crabs, and mice to sunflower seeds.

Amongst difficulties visitors have to contend with is the lack of accommodation when seeking to study birds. There are too many "wilderness areas" where birds must be sought under hard conditions ; too few where they can be watched in comfort. For example, Farewell Spit, where many interesting waders occur in large numbers, has only a lighthouse, though it is now 
possible to make a day trip along the spit when conditions are favourable. Kapiti Island and Little Barrier sanctuaries can accommodate a very limited number of visitors, whilst Stewart Island boarding houses are also limited.

There is a growing necessity to define which national parks should be "play areas" for the public and which should be looked upon as open air museums where plant and bird life must have preference to amusement. Tongariro National Park, for instance, should be looked upon as a public sports area, being mainly rough open country on the slope of a volcano. On the contrary, Tasman National Park, with its unique plant and bird life, would suffer were roads made through it.

It is a difficult matter to keep the balance at times. At this moment Lake Rotoroa (South Island) is the centre of a large hydro-electric scheme, from which this beautiful lake, the home of many interesting birds, may emerge almost unscathed. But should it be turned into a week-end resort, one of the best bird-watching places, where parrakeet, yellow-head, kaka, and many lake species are to be found, will be ruined. The Acclimatization Society, whose anglers frequent the lake, should be awake to this danger, but public pressure is very strong.

From time to time scientific expeditions are made into littleexplored parts of the Dominion where it is hoped to obtain fresh information. Areas already well explored are also revisited to ascertain any changes which may have occurred.

The 1950 expedition to Three Kings Islands, which were known to have had their unique plant life effaced by goats, belongs to the latter category. The goats have since been destroyed and recent reports suggest that it will not be long before the islands are reclothed with vegetation. This will have a bearing upon future bird life.

The Snares, Antipodes, and Bounty Islands, roughly explored in the past, have been the object of scientific investigation within recent years, chiefly to make a census of the seal population; but also to check the species of birds present. Highlights of the above expeditions were the discovery of an unsuspected colony of Cape Pigeon, the spread of Sea Elephants on to the Antipodes, and a breeding site of these mammals on the Campbells. Interesting facts concerning certain land birds were discovered. The Antipodes Islands Parrakeet feeds, it would appear, upon the contents of Rockhopper Penguins' eggs dropped by skuas. Pipits feed on flies attracted by the large colonies of albatross and penguin, even as the Tuatara lizard lives in the burrow of a petrel in order to obtain insects which 
cluster around the oily food upon which these sea birds live.

Two somewhat spectacular expeditions have been staged recently. One sponsored by U.S.A. and New Zealand interests was to Caswell Sound in order to discover the position of Moose and Wapiti since their liberation in south-west Fiordland. Dr. Murie's comment that the forest had not suffered as severely as he had expected is somewhat in line with a recent article wherein the author, Mr. M. Grant, holds that Thar and Chamois are not responsible for the damage to mountain tops which leads to erosion. He suggests that the villain of the piece is our old friend the sheep, that close grazer which has done untold damage in many parts of the world. The writer can endorse the fact that grazing on Mount Arthur Tableland (Nelson Province) over a number of years has eliminated many of the beautiful montane plants formerly so numerous.

The expedition to Caswell Sound which attracted the maximum number of scientists, and even boasted of a post office, can hardly be said to have produced much fresh data upon bird life, apart from taking prints of the now rare Kakapo Parrot. This flightless creature, being partly nocturnal, has so far evaded a record of its life habits. It is believed that the male Kakapo develops an air sac with which it booms forth a call note on years when the rata nectar is heavy, heard for a long distance to summon females, that is to say every alternate year. The female, in direct contradiction to the female kiwi, carries out all the duties of hatching and rearing a family without any assistance from her partner, until at the end of the season she is skin and bone. Possibly this is why Kakapo only breed every other year. The presence of Kakapos can be detected by the rough balls of masticated green food they eject and the narrow runways which, by biting back the vegetation, they keep clear to travel along.

The rediscovery of a large rail, the Notornis or Takahe, only four specimens of which had hitherto been secured apart from fossil bones, caused a veritable sensation in the newspaper world. The last specimen, a female caught by a dog, had contained eggs and, although no more were taken for many years, there were people who were certain that the bird still existed. Footprints, which had led to the finding of the first Notornis in 1849, in 1948 again betrayed these large editions of the common Pukeko or Waterhen of the Eastern Hemisphere. The next event was a photograph published in the press of a pair of these famous birds held head downwards by their discoverer, after the manner of domestic fowls, a most unpleasant sight to bird- 
lovers. Worse still was the fact that before steps were taken to safeguard these birds the locality and description of their hidden valley off Lake Te Anau was given out to the world.

The New Zealand Government acted with commendable promptness by declaring the area a sanctuary, and an expedition entered the valley to take movie pictures and to form an estimate of the colony. Since then it has been suggested that the numbers of Notornis have decreased owing to too much disturbance, this being countered by the statement that the original numbers may have been over-estimated. The latest information is that this flightless bird inhabits six valleys and breeds in four. The writer believes they migrate, as Nelson and Blenheim Province are alleged to have periodic visits from them.

The discovery of the Notornis has led to the suggestion that some lesser species of moa may yet lurk in the hinterland of Milford Sound, and an excellent pamphlet by W. A. Taylor, "Pictographs and Moa Hunters," gives sufficient data to show that there is more evidence for the survival of the moa than is generally believed. This idea is in direct contradiction to the school of thought which held that no moa was alive when Europeans arrived in New Zealand.

The writer has a letter wherein an elderly gentleman tells of information he obtained from an old Maori. This Maori's father remembered being told by his father that the hunters who went into the back country put the moas they killed on rafts and floated them downstream to where the tribes could assemble and eat them. This solves a problem as to why so many moa bones have been found at the mouths of rivers; a point which has hitherto baffled investigators.

The rediscovery of the Notornis has given rare bird hunting a fresh impetus, but there is plenty of work still to be done on well-known species. Little is known of the movements of the genus Gallirallus known as woodhens or "wekas", of which there are several species. These birds are wanderers which appear and disappear so that it is difficult to study their numbers and migration.

The New Zealand Ornithological Society has done good work in the past by collecting information regarding various species by means of banding or by obtaining reports from all over the Dominion. It was unfortunate that the response by the public to an appeal for data of the Shining Cuckoo, a yearly migrant to New Zealand, was somewhat meagre. Some of the members have recently collected comprehensive information and excellent photographs of the nesting habits of the rare North Island Crow. 
Under the heading "Private research work" can be grouped very detailed observation upon such birds as the Yellow-eyed Penguin, the Little Penguin, and the Royal Albatross, by Mr. Richdale. Out of this has come the fact that albatross do not abandon their chicks as hitherto believed, but continue to feed them till they leave the nest. This data was obtained from a pair of Royal Albatross which chose for their breeding site the tussock slopes of Otago Heads. This place has now been declared a sanctuary and put under supervision, Within the last few weeks it is reported that the birds have destroyed one or two of their eggs and that chicks have mysteriously disappeared. Valuable information is sometimes forthcoming from parties who enter little explored country. But whilst they may stumble upon something in the nature of a thrill, such parties are seldom long enough in one spot to form a true idea of what bird life exists in the locality.

Quite good information is obtained from notes sent in by observers to leading newspapers. A discussion about a certain species will frequently produce a spate of interesting information. The public appears to prefer to send its contributions in this manner, rather than to scientific bodies. Last but not least, data can be obtained from schoolchildren, a source which the wise observer does not overlook. The Nelson Education Board has for some years encouraged an annual competition among primary school children. This consists of nature notes in the form of a diary kept for one month in spring. In these diaries it is possible to assess how far bird protection has sunk in. This year most diaries referred to the native pigeon as "strictly protected" which shows that, at long last, the lesson has been learnt. Unfortunately, other statements reveal that, as a whole, the public has no idea what birds are protected or why it is necessary. Certain species, too, such as the Yellow-hammer and the native Yellow-head, are hopelessly confused in their minds.

Too many children refer to the "gull " or the "shag" and appear unaware that there are more than one species. Whilst most of them have been told about the wonderful Bar-tailed Godwit which migrates annually to these shores from Siberia, it is doubtful whether they would recognize this wader if they saw it. However any unusual event will promptly be recorded, as when Spine-tailed Swifts appeared during the war years. Also, should climatic conditions affect bird life, it is pretty certain that a hint of it will find its way into the diaries, as, for instance, when a sudden fall of snow killed off fantails just when they were nesting. 
It will be seen that bird study in New Zealand is not particularly easy; also that New Zealand has far fewer species than Australia, but those who are prepared to enter wilderness areas may hope to see and photograph rare birds.

Of late it would appear that certain rare species on the verge of extinction have staged a "come-back" and may possibly survive. One of these is the Laughing Owl, which has recently been rediscovered.

In a former article in this journal ${ }^{1}$ the writer discussed the effect of civilization upon New Zealand. Unfortunately most of the problems remain the same. Old pests are only a little less numerous and some have been added, such as termites and the Sirex noctilio (wasp spp.). Perhaps the most sinister fact of all is the rapid increase of opossums. Their ravages have become so obvious that it might be alleged that we have in New Zealand another pest as serious as the rabbit, a climbing rabbit so to speak.

Whilst man has at last awoken to the value of wild life, the toll taken by introduced pests is increasing, so one cannot predict the future of the forest-inhabiting birds of New Zealand.

\section{BIRDS OF NEW ZEALAND}

(In the order of their mention in the preceding article)

North Island Robin (Miro longipes).

South Island Robin (Miro australis).

Antipodes Island Parrakeet (Cyanoramphus unicolor).

Snares Island Robin (Miro dannefaerdi)

Stephen Island Wren (Taversia lyalli).

Black Woodhen (Gallirallus troglodytes).

North Island Woodhen (Gallirallus greyi).

South Island Woodhen (Gallirallus australis).

North Island Kiwi (Apteryx mantelli).

Little Grey Kiwi (Apteryx oweni).

South Island Kiwi (Apteryx australis).

Saddleback (Creadion carunculatus).

Sooty Shearwater (Puffinus griseus).

Royal Albatross (Diomedia epomophora).

Giant Petrel (Macronectes giganteus).

Yellow-eyed or Grand Penguin (Megadyptes antipodes).

Rockhopper Penguin (Eudyptes chrysocome).

Little Penguin Eudyptula minor).

Pied Shag (Phalacrocorax varius).
Rough-faced Shag (Phalacrocorax carunculatus).

Bronze Shag (Phalacrocorax carunculatus chalconotus).

Spotted Shag (Phalacrocorax punctatus).

Black Shag (Phalacrocorax carbo).

Blue Shag (Phalacrocorax carbo steadi).

White Egret (Egretta alba).

Reef Heron (Demigretta sacra).

White-faced Heron (Notophoyx novaehollandiae).

Stitchbird (Notiomystis cincta).

Kea (Nestor notabilis).

North Island Brown Kaka (Nestor septentrionalis).

South Island Green Kaka (Nestor meridionalis).

Rifleman (Acanthisitta chloris).

Rock-Wren (Xenicus gilviventris).

Brown Creeper (Finschia novaeseelandiae).

Pied, North Island or White-breasted Tit (Petroica toitoi).

Yellow-breasted or South Island Tit (Petroica macrocephala).

1 S.P.F.E. Journal, XLIX. 
Blue-wattled or North Island Crow (Callaeas wilsoni).

Orange-wattled or South Island Crow (Callaeas cinerea).

North Island Thrush (Tanagra tanagra)

South Island Thrush (Tanagra capenis).

Whitehead (Mohoua albicilla).

Yellowhead (Mohoua ochrocephela).

Black Fantail (Rhipidura fuliginosa).

Pied Fantail (Rhipidura flabellifera).

Grey Warbler (Pseudogerygone igata).

Shining Cuckoo (Lamprococcyx lucidus).

Australian Swamp Quail (Synoicus ypsilophorus).

Californian Quail (Callipepla californica).

New Zealand Quail (Coturnix novaeseelandiae).

Chukor (Alectoris graeca).

New Zealand Harrier (Circus approximans).
New Zealand Falcon or Bush Hawk (Falco novaeseelandiae).

Paradise Duck (Tadorna variegata).

Blue or Mountain Duck (Hymenolaimus malacorhynchos).

New Zealand Owl or Morepork (Ninox novaeseelandiae).

White-eye (Zosterops halmaturina).

Bellbird (Anthornis melanura).

Tui (Prosthemadura novaeseelandiae).

Kingfisher (Halcyon sanctus).

Cape Pigeon or Pintado Petrel (Daption capense).

Kakapo Parrot (Strigops habroptilus).

Takahe or Notornis (Notornis hochstetteri).

Yellowhammer (Emberiza citrinella).

Bar-tailed Godwit (Limosa lapponica).

Spine-tailed Swift (Hirundapus caudatus).

Laughing Owl (Sceloglaux albifacies).

\section{THE RED SQUIRREL}

The interest of members of the Society in the fate of the Red Squirrel and its presumed supplantation by the Grey has led to an interesting inquiry. The Director-General of the Nature Conservancy, Captain Cyril Diver, very kindly got in touch with Mr. Charles Elton, of the Bureau of Animal Population, who sent for our use a report by Miss Monica Shorten of a survey carried out by her in 1944-45 on the distribution of the two squirrels. Captain Diver also consulted Sir William Ling Taylor, C.B.E., late Director-General of the Forestry Commission, who has kindly allowed us to make use of the reply he gave. We have also to thank Dr. Maurice Burton for his article "The Chequered Story of Red Squirrels" in the Illustrated London Neres of 7th April, 1951.

As Dr. Burton points out, the two squirrels occupy different habitats. The Red prefers dense woods, either coniferous or fir and oak mixed; the Grey open woodland or parkland. Only where these habitats overlap is competition between the species very likely.

Before blaming the Grey for the diminution of the Red, the past history of the Red must be borne in mind, and Dr. Burton writes of 20,000 squirrels being sold annually in London round about 1837. His conclusion is that man and not the Grey Squirrel has pushed the Red Squirrel out.

Miss Monica Shorten's survey showed that the Red Squirrel 